\title{
Utilization of Organic Wastes in the Production of Biofertilizer (by Vermicompost using Eisenia fetida Earthworm) with Analysis of their Micro and Macro Mineral Nutrient and their Effects on Growth Rate of Fruited Pumpkin (Telfairia occidentalis) and Spinach (Spinacia oleracea)
}

\section{Obianuju Ozioma Ezeorji1*, Arinze Jude Chinweuba ${ }^{1}$, Chinedu Chibuzor Onuorah ${ }^{2}$ and Innocent Nwazulu Okwunodolu ${ }^{2}$}

${ }^{1}$ Department of Pure and Industrial Chemistry, Chukwuemeka Odumegwu Ojukwu University Uli, Anambra State, Nigeria

${ }^{2}$ Department of Food Science and Technology, Micheal Okpara University of

Agriculture, Umudike Abia State, Nigeria

*Corresponding Author: Obianuju Ozioma Ezeorji, Department of Pure and Industrial Chemistry, Chukwuemeka Odumegwu Ojukwu University Uli,

Anambra State, Nigeria.

DOI: 10.31080/ASNH.2020.04.0620
Received: January 11, 2020

Published: January 24, 2020

(C) All rights are reserved by Obianuju Ozioma Ezeorji., et al.

\begin{abstract}
Utilization of organic wastes in the production of biofertilizers (by vermicompost method) with analysis of their micro and macro nutrients was done to ascertain their efficiency in farming against synthetic fertilizer. In this bio-conversion process, earthworms feed on the farm wastes products. Farm wastes (Water melon, Cucumber, Orange, Garden egg and Pawpaw) were blended with Cow dung manure and Pig slurry in the ratio of 5: 1 and vermicomposted for 30 days in an earthen pot using Eisenia fetida earthworm species. Temperature, $\mathrm{pH}$ and moisture content were daily monitored. Both the vermicompost and the synthetic fertilizer were used for the cultivation of Spinach (vegetable green) and fruited pumpkin (ugu). The analysis of the micro and macro mineral nutrients of the vermicompost and the synthetic fertilizer were done using Atomic Absorption Spectroscopy. The results of the vermicompost of all the samples showed that the micro nutrients of the four vermicompost samples A-D plus N.P.K ranged as follows Fe $(0.06 \pm 0.01-$ $38.03 \pm 0.04 \mathrm{mg} / \mathrm{kg}), \mathrm{Cu}(35.30 \pm 0.14-59.59 .53 \pm 0.04 \mathrm{mg} / \mathrm{kg}), \mathrm{Zn}(0.6 \pm 0.01-9.65 \pm 0.07 \mathrm{mg} / \mathrm{kg}), \mathrm{Mn}(0.13 \pm 0.04-30.05 \pm 0.07 \mathrm{mg} /$ $\mathrm{kg}$ ) while macro mineral nutrient are as follows Mg (1.02 $\pm 0.030-3.53 \pm 0.04 \mathrm{mg} / \mathrm{kg}), \mathrm{Ca}(1.02 \pm 0.01-22.55 \pm 0.07 \mathrm{mg} / \mathrm{kg}), \mathrm{N}(20.05$ $\pm 0.07-27.23 \pm 0.04 \mathrm{mg} / \mathrm{kg}), \mathrm{P}(10.06 \pm 0.08-30.10 \pm 0.14 \mathrm{mg} / \mathrm{kg}), \mathrm{K}(10.02 \pm 0.02-37.05 \pm 0.07 \mathrm{mg} / \mathrm{kg})$. Generally the four vermicompost samples had high content of micro and macro mineral nutrients than N.P.K due to the action of the earth worm which helps in converting of organic matter into mineral nutrient. They also had a better performance in terms of growth rate compared to samples planted with normal N.P.K fertilizer and control soil samples, due to nutrient balance in organic manure which affects plant growth and development compared to chemical fertilizer. Vermicomposting can be used as a wastes product management strategy and at same time, obtain biofertilizers which are environmental friendly.
\end{abstract}

Keywords: Organic Waste; Biofertilizer; Vermicompost; Micro and Macro Mineral Nutrient, Growth Rate

\section{Introduction}

The increasing world population has tremendous pressure on land use and other natural resources causing damages to the ecological domain [1]. The increased crop production over the years has also accelerated the removal of plant nutrient four times during the last four decades thereby reducing soil nutrient and stability. Chemical fertilizer has contributed positively to the increase in world food productions [2]. It is worthy to note that continuous use of chemical fertilizer does not develop good plant character such as good root system, shoot system, nutritional characters and also will not get enough time to grow and mature properly [3]. Chemically produced plant will accumulate in human body, toxic chemicals which are very dangerous. To minimize the ac- cumulation of pollutants in agro-ecosystems we should avoid the use of toxic chemicals especially synthetic fertilizer hence the use of organic eco-friendly and environmentally safe bio-fertilizer and vermicompost becomes very vital [2]. Organic waste are mostly by-products of agricultural activities, these include crop residual stalks, straw, leaves, roots, husks, shell) and animal waste (manure) [4]. These waste can enhance food production through the use of bio-fertilizers which are becoming popular, they are materials which contains living micro-organism which when applied to plant surfaces they promote growth by increasing the supply of primary nutrients to the host plant [5]. They add nutrient through natural processes such as nitrogen fixation, solubilizing phosphorus and stimulating plant growth along with the synthesis of growth pro- 
Utilization of Organic Wastes in the Production of Biofertilizer (by Vermicompost using Eisenia fetida Earthworm) with Analysis of their Micro and Macro Mineral Nutrient and their Effects on Growth Rate of Fruited Pumpkin (Telfairia occidentalis) and Spinach (Spinacia oleracea)

moting substances. They are natural product carrying living micro organisms derived from the root or cultivated soil [6] having no ill effect on soil health and environment. Bio-fertilizer are cheap to produce, does not create pollution in the natural system [7]. The rising importance of bio-fertilizers and the result will be helpful in the renewal of environment. Bio-fertilizers are basically grouped in different way based on their nature and function $[8,9]$. These include Rhizobium, Azotobacter, Azaspirillum, Cyanobacteria, Azolla, Phosphate solubilizing micro-organisms (PSM), Arbuscular mycorrhiza fungi, Silicate Solution bacteria and growth promoting rhizobacteria [10]. There are many micro-organisms which are found in various biofertilizer produced by different researcher that are beneficial to both plants and soil as well [9]. Although there are many methods of bio-fertilizer production, vermicomposting which is the process of producing compost by utilizing earthworms to turn the organic waste into high quality compost that consists mainly of worm cast in addition to decayed organic matter [11]. Vermicomposting has turned out to be promising way out for safe disposal of organic waste. They help in conversion of organic waste (agro-waste, animal manure and domestic refuse into highly nutrient fertilizer for plants and soil [12]. It involves the technique of biodegradation or stabilization of organic waste (natural anthropogenic) by using earth worms and microbes [2] Vermicompost is rich in nitrogen, phosphorus, potassium, micronutrients and other beneficial soil microbes (nitrogen fixing and phosphate solubilizing bacteria) [31]. It is a sustainable alternative to chemical fertilizers, which is an excellent growth promoter and protector for crop and plants [13]. Different organic waste material like rice straw, dry grass, chippings, cow dung, dry leaves, rotten watermelon, papaya, pine apple, custard apple and guava has been used in preparing vermicompost biofertilizer $[2,9,13]$. Eisenia fetida specie of earth are mostly used in vermicompost due to their ability to consume large quantities of organic matter and excrete it as nutrients, which are beneficial for bacteria and mycorrhizea. When an organic material passes through the gut of earth worm, it increases the surface area of the material so that micro-organisms can break it down further [14]. Various studies on the production of vermicompost using biodegradable waste indicated its efficiency and cost effectiveness in reducing the application of chemical fertilizer up to $100 \%$ for various vegetable and crops [15]. Soil mineral are divided into two types macro and micro nutrient based on the amount needed by plant to grow [16] The fourteen mineral nutrients are classified as either micro or macro nutrients based on their requirement and relative fertilization need [5]. There are basically six macro minerals, nitrogen, phosphorus, potassium, calcium, magnesium and Sulphur $[17,18]$. Micro-mineral are essential for plant growth, but plants requires relatively small amount of them, hence the term micro. They include boron, chlorine, copper, iron, manganese, molybdenum and zinc [13]. Generally bio-fertilizers produced through vermicom- post method are rich in micro and macro-nutrients which are very vital in soil nutrient enrichment [9]. This study therefore aimed at using organic waste in producing bio-fertilizer by vermicompost method using (Eiesena fetida) earth worm specie also to determine the micro and macro mineral content, its comparative effect on Fruited pumpkin (Telfairia occidentalis) and Spinach (Spinacia oleracea) growth rate. Comparing it with normal chemical fertilizer (N.P.K 15:15:20) and control (normal sand loamy soil).

\section{Materials and Methods \\ Materials}

These include transparent plastic container, weighing balance, stirrer, 20mesh sieve, farming tools (hoe, watering can and cutlass) meter tape, water melon, cucumber, orange, garden egg, paw-paw (Carica papaya), cucumber (Cucumis sinesis) and earthworm (Eisenia fetida), Cow dung, Pig slurry, water, soil and synthetic fertilizer (N.P.K) 15:15:20.

\section{Sample collection}

Discarded water melon (Citrullus lanatus), paw-paw (Carica papaya), Cucumber (Cucumi sinesis), garden egg (Solenum melongena) and orange (Citrus $x$ sinesis) were collected from a dump site in Nkwogbe Market Ihiala, Anambra State Nigeria. The Cow dung used as inoculums was collected from an abattoir in the same region mentioned above. Eisenia fetida were collected near a stream location at Oba, Idemili North Local Government Area, Anambra State. It was cultured and kept for the experiment.

\section{Sample preparation}

Step one

The sample material from the municipal waste farm product were separately grinded to increase the surface area and sieved, allowed passage through a 20 mesh sieve ( $1 \mathrm{~mm}$ diameter screen) after which each of the sample materials were isolated in a different container, were the sample was weighed from. The containers were labeled $\mathrm{A}$ to $\mathrm{D}$.

\section{Preparation of vermicompost}

The method described by [30], was used in the preparation with slight modification in the organic materials used. Vermicompost preparation was done by mixing the samples labeled A to D with Cow dung and big slurry. The weighing was done at different measurement and ratio as shown in the table 1 above except for the Pig slurry, Cow-dung and water (to dilute it) while the measurement remained constant. They were all weighed into different containers labeled A to D and constantly stirred with 4 (four) liters of distilled water. The mixture was put in an earthen pot containing the earth worm (a transparent double fitted plastic container with the inner one perforated to allow passage of excess water, also labeled A-D which is already filled with sterilized loamy soil to about $2.0 \mathrm{~cm}$ ). The mixture was allowed to pre-decompose for 15 days with intermittent turning. The earthen was covered with jute bag to maintain 
Utilization of Organic Wastes in the Production of Biofertilizer (by Vermicompost using Eisenia fetida Earthworm) with Analysis of their Micro and Macro Mineral Nutrient and their Effects on Growth Rate of Fruited Pumpkin (Telfairia occidentalis) and Spinach (Spinacia oleracea)

113

Sample Garden egg (kg) Water melon (kg) Orange (kg) Cucumber (kg) Paw-paw (kg) Cow dung (kg) Pig Slurry (kg) Water (kg)

\begin{tabular}{|l|c|c|c|c|c|c|c|c|}
\hline A & 15 & 17 & 3 & 5 & 10 & 2 & 2 & 3.5 \\
\hline B & 15 & 5 & 15 & 5 & 10 & 2 & 2 & 3.5 \\
\hline C & 15 & 10 & 10 & 10 & 15 & 2 & 2 & 3.5 \\
\hline D & 30 & 5 & 5 & 5 & 5 & 2 & 2 & 3.5 \\
\hline
\end{tabular}

Table 1: Sample formulation table.

proper humidity and heat required by Eisenia fetida for effective bio conversion of sample materials to organic fertilizer. The set up was allowed for 60 days. Water was sprinkled intermittently to maintain adequate moisture required and the temperature was monitored with the aid of an inserted thermometer between 29$30^{\circ} \mathrm{C}$ for optimum conversion. Appearance of sticky black coarse mat on the surface of the vermicompost signaled complete conversion.

\section{Mineral analysis}

The macro and micro mineral content of the vermicompost samples were analyzed using atomic absorption spectrophotometer described by [19] for magnesium, calcium, potassium, iron zinc and manganese. Phosphorus copper and nitrogen were determined by the method described by [28].

Cultivation and growth monitoring

After the complete conversion of the vermicompost, it was then used for cultivation. The normal farming process took place which includes clearing of farm land and preparation of the beds. $6 \mathrm{~kg}$ of each of the vermicompost samples (A-D) was then mixed with the soil and water. Then the six different beds were prepared 2 meters distance from each other, one been control. The bed was continuously watered for 2 days, morning and evening before planting. The bed formation and planting arrangement was done based on the table 2 below.

\begin{tabular}{|l|c|c|c|c|c|}
\hline $\begin{array}{c}\text { Vermicompost } \\
\text { sample A mixed } \\
\text { with Sandy loamy } \\
\text { soil }\end{array}$ & $\begin{array}{c}\text { Vermicompost } \\
\text { sample B mixed } \\
\text { with Sandy loamy } \\
\text { soil }\end{array}$ & $\begin{array}{c}\text { Vermicompost } \\
\text { sample C mixed } \\
\text { with Sandy loamy } \\
\text { soil }\end{array}$ & $\begin{array}{c}\text { Vermicompost } \\
\text { sample D mixed } \\
\text { with Sandy loamy } \\
\text { soil }\end{array}$ & $\begin{array}{c}\text { N.P.K 15:15:20 fer- } \\
\text { tilizer mixed with } \\
\text { Sandy loamy soil }\end{array}$ & $\begin{array}{c}\text { Normal Sandy Soil } \\
\text { (control) }\end{array}$ \\
\hline Spinach & Fruited pumpkin & Spinach & Fruited pumpkin & Spinach & Fruited pumpkin \\
\hline Fruited pumpkin & Spinach & Fruited pumpkin & Spinach & Fruited pumpkin & Spinach \\
\hline
\end{tabular}

Table 2: Bed formulation and planting format.

\section{Planting and monitoring}

The planting of both seeds was done based on the table 2 above with a distance of 1.5 meters from each other. The germination took place 4 days after cultivation on $14^{\text {th }}$ October 2017 and monitoring of growth took place between a period of 30 days during which the height of the stem were measured followed by the length and width of the leave using a meter tape and meter rule.

\section{Statistical analysis}

Completely randomized design (CRD) by [20] was used. Mean value of all the duplicate analytical determinations were subjected to analysis of variance (ANOVA). Significant difference were determine using SPSS statistical tools version 21 at $5 \%(\mathrm{P}<0.05)$ acceptable level.

\section{Result and Discussion}

Mineral analysis

The result of the micro and macro mineral nutrient of the four vermicompost fertilizer samples (A-D) plus the N.P.K $(15: 15: 20)$ fertilizer sample were presented in table 3 and table 4 below;

\begin{tabular}{|l|c|c|c|c|c|}
\hline Micro-mineral & $\begin{array}{c}\text { Vermicompost } \\
\text { sample A }\end{array}$ & $\begin{array}{c}\text { Vermicompost } \\
\text { sample B }\end{array}$ & $\begin{array}{c}\text { Vermicompost } \\
\text { Sample C }\end{array}$ & $\begin{array}{c}\text { Vermicompost } \\
\text { sample D }\end{array}$ & $\begin{array}{c}\text { N.P.K } \\
(\mathbf{1 5 : 1 5 : 2 0 )}\end{array}$ \\
\hline $\mathrm{Fe}(\mathrm{mg} / \mathrm{kg})$ & $30.08^{\mathrm{c}} \pm 0.11$ & $28.85^{\mathrm{d}} \pm 0.07$ & $38.30^{\mathrm{a}} \pm 0.04$ & $30.58^{\mathrm{d}} \pm 0.11$ & $0.06^{\mathrm{e}} \pm 0.01$ \\
\hline $\mathrm{Cu}(\mathrm{mg} / \mathrm{kg})$ & $36.05^{\mathrm{c}} \pm 0.07$ & $35.30^{\mathrm{d}} \pm 0.14$ & $59.53^{\mathrm{a}} \pm 0.14$ & $50.08^{\mathrm{b}} \pm 0.11$ & $0.0^{\mathrm{e}} \pm 0.00$ \\
\hline $\mathrm{Zn}(\mathrm{mg} / \mathrm{kg})$ & $7.09^{\mathrm{c}} \pm 0.13$ & $9.65^{\mathrm{a}} \pm 0.07$ & $8.25^{\mathrm{b}} \pm 0.07$ & $6.07^{\mathrm{d}} \pm 0.09$ & $0.06^{\mathrm{e}} \pm 0.01$ \\
\hline $\mathrm{Mn}(\mathrm{mg} / \mathrm{kg})$ & $29.85^{\mathrm{b}} \pm 0.07$ & $30.05^{\mathrm{a}} \pm 0.07$ & $29.78^{\mathrm{c}} \pm 0.11$ & $24.04^{\mathrm{d}} \pm 0.06$ & $0.13^{\mathrm{e}} \pm 0.04$ \\
\hline
\end{tabular}

Table 3: Micro-mineral composition of four Vermicompost (A-D) sample and N.P.K (15:15:20).

Values are mean duplicate determinations with \pm standard deviation. Similar superscripts on the same row are not significantly different $(\mathrm{P}<0.05)$.

Citation: Obianuju Ozioma Ezeorji., et al. "Utilization of Organic Wastes in the Production of Biofertilizer (by Vermicompost using Eisenia fetida Earthworm) with Analysis of their Micro and Macro Mineral Nutrient and their Effects on Growth Rate of Fruited Pumpkin (Telfairia occidentalis) and Spinach (Spinacia oleracea)". Acta Scientific Nutritional Health 4.2 (2020): 111-120. 
Utilization of Organic Wastes in the Production of Biofertilizer (by Vermicompost using Eisenia fetida Earthworm) with Analysis of their Micro and Macro Mineral Nutrient and their Effects on Growth Rate of Fruited Pumpkin (Telfairia occidentalis) and Spinach (Spinacia oleracea)

Micro mineral nutrient

Iron $(\mathrm{Fe}) \mathrm{mg} / \mathrm{kg}$

Iron is the first micro-element which is necessary for plant life. It plays an important role in chlorophyll biosynthesis pathway [32]. The iron content of the four vermicompost fertilizer samples (A-D) are $(30.08 \pm 0.11 \mathrm{mg} / \mathrm{kg}, 28.85 \pm 0.07 \mathrm{mg} / \mathrm{kg}, 38.03 \pm 0.04 \mathrm{mg} / \mathrm{kg}$ and $30.58 \pm 0.11 \mathrm{mg} / \mathrm{kg}$ ) respectively while N.P.K (15:15:20) fertilizer had $(0.06 \pm 01 \mathrm{mg} / \mathrm{kg})$. There is a significant difference among the five samples at $(\mathrm{P}<0.05)$. The range is higher compared to the report of of [31], however it partly agreed with the report of [30]. The high iron content in the vermicompost fertilizer sample especially sample $\mathrm{C}$ may be from the release of excess amount of iron and heavy metal from the earthworm body into the environment through the calciferous glands [31]. The use of vermicompost fertilizer for cultivation can be of immense benefit in supplying iron to the soil which aids synthesis of chlorophyll that promotes photosynthesis. It also supports electron transfer and nitrogen fixation in plants.

\section{Copper (Cu) mg/kg}

Copper is involved in the activation of several enzyme systems and apparently cannot be replaced by other metal ions. It is responsible for healthy vigorous growth, strengthening stalk, stem and branches [21]. The four vermicompost fertilizer samples had copper range of $(36.05 \pm 0.07 \mathrm{mg} / \mathrm{kg}, 35.30 \pm 0.14 \mathrm{mg} / \mathrm{kg}, 59.53 \pm$ $0.04 \mathrm{mg} / \mathrm{kg}$ and $50.08 \pm 0.11 \mathrm{mg} / \mathrm{kg}$ ) respectively while N.P.K fertilizer sample had zero trace of copper. The range slightly differs from [13]. The copper content of the five samples differs significantly $(\mathrm{P}<0.05)$. Samples $(\mathrm{C}$ and $\mathrm{D})$ had a very high iron content which may be from the ratio of organic matter used during the preparation. The organic matters used in formulating the samples might posses copper oxidizing enzymes [32]. Copper is directly involved in cell wall formation in plants.

\section{Zinc (Zn) mg/kg}

Zinc is a metal component of several enzyme systems that functions as electron transfer mechanisms and protein synthesis and degradation in plants. The zinc content of the four vermicompost samples (A-D) are $(7.09 \pm 0.13 \mathrm{mg} / \mathrm{kg}, 9.65 \pm 0.07 \mathrm{mg} / \mathrm{kg}, 8.25 \pm$ $0.07 \mathrm{mg} / \mathrm{kg}$ and $6.07 \pm 0.09 \mathrm{mg} / \mathrm{kg}$ ) respectively, while N.P.K had $(0.06 \pm 0.01 \mathrm{mg} / \mathrm{kg})$. The range tallied with $[30,31]$. The low zinc content of the N.P.K fertilizer sample may be from the blend used during industrial production. Zinc is one the important essential micro-mineral needed by plant which is involved in the formation of chlorophyll and carbohydrate.

\section{Manganese (Mg) mg/kg}

Manganese functions as an activator of enzymes that is involved in the evolution of oxygen in photosynthesis. The manganese content of the four vermin-compost fertilizer samples (A-D) are as follows $(29.85 \pm 0.07 \mathrm{mg} / \mathrm{kg}, 30.0 .5 \pm 0.07 \mathrm{mg} / \mathrm{kg}, 29.75 \pm 0.11 \mathrm{mg} /$ $\mathrm{kg}$ and $24.04 \pm 0.06 \mathrm{mg} / \mathrm{kg}$ ) respectively while N.P.K fertilizer recorded $(0.13 \pm 0.04 \mathrm{mg} / \mathrm{kg})$. The range agreed with Chinweuba., et al. (2017) report. The above five samples differs significantly $(\mathrm{P}<0.05)$. Manganese is involved in pollen tube growth germination, pollen tube growth, root cell elongation and resistance to pathogens. It is an essential element for plant, intervening in several metabolic processes mainly in photosynthesis and as an enzyme antioxidant-cofactor [22].

Macro mineral content

\begin{tabular}{|l|c|c|c|c|c|}
\hline Macro-mineral & $\begin{array}{c}\text { Vermicompost } \\
\text { sample A }\end{array}$ & $\begin{array}{c}\text { Vermicompost } \\
\text { sample B }\end{array}$ & $\begin{array}{c}\text { Vermicompost } \\
\text { sample C }\end{array}$ & $\begin{array}{c}\text { Vermicompost } \\
\text { sample D }\end{array}$ & N.P.K (15:15:20) \\
\hline $\mathrm{Mg}(\mathrm{mg} / \mathrm{kg})$ & $3.40^{\mathrm{b}} \pm \mathbf{0 . 1 4}$ & $3.5^{\mathrm{a}} \pm \mathbf{0 . 0 4}$ & $2.85^{\mathrm{e}} \pm \mathbf{0 . 0 7}$ & $2.25^{\mathrm{d}} \pm \mathbf{0 . 0 7}$ & $1.02^{\mathrm{e}} \pm \mathbf{0 . 0 3}$ \\
\hline $\mathrm{Ca}(\mathrm{mg} / \mathrm{kg})$ & $20.50^{\mathrm{b}} \pm \mathbf{0 . 1 4}$ & $22.55^{\mathrm{a}} \pm \mathbf{0 . 0 7}$ & $18.90^{\mathrm{c}} \pm \mathbf{0 . 0 0}$ & $15.75^{\mathrm{d}} \pm \mathbf{0 . 0 7}$ & $1.01^{\mathrm{e}} \pm \mathbf{0 . 0 1}$ \\
\hline $\mathrm{N}(\mathrm{mg} / \mathrm{kg})$ & $22.40^{\mathrm{c}} \pm \mathbf{0 . 1 4}$ & $24.25^{\mathrm{b}} \pm \mathbf{0 . 0 7}$ & $20.35^{\mathrm{d}} \pm \mathbf{0 . 0 7}$ & $27.23^{\mathrm{a}} \pm \mathbf{0 . 0 4}$ & $20.03^{\mathrm{e}} \pm 0.07$ \\
\hline $\mathrm{P}(\mathrm{mg} / \mathrm{kg})$ & $29.85^{\mathrm{b}} \pm \mathbf{0 . 0 7}$ & $30.10^{\mathrm{a}} \pm \mathbf{0 . 1 4}$ & $24.56^{\mathrm{c}} \pm \mathbf{0 . 0 8}$ & $20.08^{\mathrm{a}} \pm \mathbf{0 . 1 1}$ & $10.06^{\mathrm{e}} \pm 0.08$ \\
\hline $\mathrm{K}(\mathrm{mg} / \mathrm{kg})$ & $37.05^{\mathrm{a}} \pm \mathbf{0 . 0 7}$ & $19.51^{\mathrm{d}} \pm \mathbf{0 . 1 4}$ & $33.28^{\mathrm{b}} \pm \mathbf{0 . 0 4}$ & $30.37^{\mathrm{c}} \pm \mathbf{0 . 0 4}$ & $10.02^{\mathrm{e}} \pm 0.02$ \\
\hline
\end{tabular}

Table 4: Macro-mineral composition of four Vermicompost (A-D) sample and N.P.K (15:15:20).

Values are mean duplicate determinations with \pm standard deviation. Similar superscripts on the same row are not significantly different $(\mathrm{P}<0.05)$.

\section{Magnesium (Mg) mg/kg}

Magnesium is very important soil mineral nutrient that is vital for chlorophyll synthesis. It plays important role in plant defense mechanisms [23]. The magnesium content of the four vermincompost fertilizer sample (A-D) plus N.P.K (15:15:20) are (3.40 \pm $0.14 \mathrm{mg} / \mathrm{kg}, 3.53 \pm 0.04 \mathrm{mg} / \mathrm{kg}, 2.85 \pm 0.07 \mathrm{mg} / \mathrm{kg}, 2.25 \pm 0.07 \mathrm{mg} /$ $\mathrm{kg}$ and $1.02 \pm 0.03 \mathrm{mg} / \mathrm{kg}$ ) respectively. The five samples differs sig- nificantly at $(\mathrm{P}<0.05)$, the range of magnesium among the four vermicompost samples tallied with [30], but slightly differ from Devi and Sumathy [9]. The slight difference among sample (A-D) can be attributed to the initial magnesium content of the organic materials used for the production of the vermin-compost plus the ratio of formulation. The low magnesium content in the N.P.K may be due to the fact that magnesium was not among the major constituents 
Utilization of Organic Wastes in the Production of Biofertilizer (by Vermicompost using Eisenia fetida Earthworm) with Analysis of their Micro and Macro Mineral Nutrient and their Effects on Growth Rate of Fruited Pumpkin (Telfairia occidentalis) and Spinach (Spinacia oleracea)

used during the production. Chemical fertilizers are formulated based on chemical ratio required except for single fertilizer. Magnesium is a central component of chlorophyll which is supporting the function to absorb sunlight during photosynthesis.

\section{Calcium (Ca) $\mathrm{mg} / \mathrm{kg}$}

Calcium contributes greatly in the fruit and seed formulation in plants. The calcium content of the four vermicompost fertilizer sample and N.P.K (15:15:20) fertilizer are $(20.50 \pm 0.14 \mathrm{mg} /$ $\mathrm{kg}, 22.55 \pm 0.07 \mathrm{mg} / \mathrm{kg}, 18.90 \pm 0.00 \mathrm{mg} / \mathrm{kg}$ and $15.75 \pm 0.07 \mathrm{mg} /$ $\mathrm{kg}$ ) respectively while N.P.K fertilizer had $1.01 \pm 0.01 \mathrm{mg} / \mathrm{kg}$. The five samples differs significantly $(\mathrm{P}<0.05)$. The range is similar to [30] report. The high content of calcium in the four samples (A-D) makes them perfect for cultivation since chemical fertilizer alone does not provide all essential minerals needed by the soil [5] Calcium is needed in cell elongation and cell division, it influence structural stability and permeability of cell membranes of plants.

\section{Nitrogen (N) mg/kg}

Nitrogen is one of the most essential macro mineral nutrients required by plant; it is considered the most important component for supporting plant growth. Nitrogen is part of the chlorophyll molecule, which gives plants their green colour. The nitrogen content of N.P.K (15:15:20) fertilizer and vermicompost samples (AD) are as follows $(20.05 \pm 0.07 \mathrm{mg} / \mathrm{kg}, 22.40 \pm 0.14 \mathrm{mg} / \mathrm{kg}, 24.25$ $\pm 0.07 \mathrm{mg} / \mathrm{kg}, 20.35 \pm 0.07 \mathrm{mg} / \mathrm{kg}$ and $27.23 \pm 0.14 \mathrm{mg} / \mathrm{kg}$ ) respectively. The range partly agreed with the report of [31]. The high content of nitrogen in the four vermicompost samples (A-D) may be due to the ability of crops to absorb nitrogen through the roots which are released during composting. Besides releasing nitrogen from compost materials, earthworms also enhance nitrogen level by adding their excretory products, mucus and body fluid to the substrate [31]. Nitrogen is considered as the most important component for supporting plant growth.

\section{Phosphorus (P) mg/kg}

Phosphorus is essential for all living organisms. It plays a role in photosynthesis, respiration, energy storage and transfer, cell division, cell enlargement and several other plant processes. The phosphorus content of the samples (A-D) are $(29.85 \pm 0.07 \mathrm{mg} / \mathrm{kg}$, $30.10 \pm 0.14 \mathrm{mg} / \mathrm{kg}, 24.56 \pm 0.08 \mathrm{mg} / \mathrm{kg}$ and $20.08 \pm 011 \mathrm{mg} / \mathrm{kg}$ ) respectively. While N.P.K $(15: 15: 20)$ had $10.06 \pm 0.14 \mathrm{mg} / \mathrm{kg}$. The range recorded by samples (A-D) differs slightly with the report of $[14,31]$. The slight difference may be from the initial organic matter used for the vermicompost preparation. The high content of phosphorus in sample (A-D) compared to N.P.K (15:15:20) may be from the mineralization and mobilization of phosphorus by bacteria and fecal phosphate activity of earth worm [24].

\section{Potassium (K) mg/kg}

Potassium enhances enzyme activation, improves crop quality and protein synthesis in plant [25]. The potassium content of sample (A-D) are as follows $(37.05 \pm 0.07 \mathrm{mg} / \mathrm{kg}, 19.51 \pm 0.14 \mathrm{mg} /$ $\mathrm{kg}, 33.28 \pm 0.04 \mathrm{mg} / \mathrm{kg}$ and $30.37 \pm 0.04 \mathrm{mg} / \mathrm{kg}$ respectively while N.P.K $(15: 15: 20)$ had $10.20 \pm 0.02 \mathrm{mg} / \mathrm{kg})$. The five sample differs significantly $(\mathrm{P}<0.05)$. The phosphorus content of samples $(\mathrm{A}-\mathrm{D})$ is greater than N.P.K $(15: 15: 20)$. This may be due to the possible exchange of potassium from enhanced microbial activities during vermicomposting [26]. Generally, vermicomposting generate high amount of potassium which can be vital for plant growth. Potassium is associated with water movement, nutrients and carbohydrate in plant tissue.

Monitoring of growth of UGU (pumpkin) and spinach Comparison of average length of stem cord of pumpkin

The above chart showed average length of the stem cord of Fruited Pumpkin as it was measured for a period of 30 days. The four Vermicompost samples, N.P.K fertilizer and Control (normal sandy loamy) was used in the cultivation. The length of the stem cord of pumpkin on the (6) different soil treatment showed that sample A vermicompost treatment had the highest length range after 30 days, measuring $(65.0 \mathrm{~cm}-368.4 \mathrm{~cm})$ followed by sample C $(77.0 \mathrm{~cm}-366.3 \mathrm{~cm}), B(76.2 \mathrm{~cm}-338.5 \mathrm{~cm})$ and D $(78.9 \mathrm{~cm}$ $327.2 \mathrm{~cm})$ sample treatments while N.P.K $(65.8 \mathrm{~cm}-322.8 \mathrm{~cm})$ and Control $(66.2 \mathrm{~cm}-280.5 \mathrm{~cm})$ had the least respectively.

\section{Comparison of average length of pumpkin leaves}

The average length of the Fruited Pumpkin showed that sample A $(12.2 \mathrm{~cm}-22.5 \mathrm{~cm})$ treatment had the highest leaf length after 30 days, followed by sample C $(10.4 \mathrm{~cm}-22.0 \mathrm{~cm})$ treatment, N.P.K $(10.1 \mathrm{~cm}-20.6 \mathrm{~cm})$ fertilizer treatment and sample B $(10.2 \mathrm{~cm}-$ $20.0 \mathrm{~cm})$ treatment while sample D $(10.4 \mathrm{~cm}-18.8 \mathrm{~cm})$ treatment and control $(9.10 \mathrm{~cm}-18.5 \mathrm{~cm})$ samples had the lowest average leave length respectively.

\section{Comparison of average leave width of pumpkin}

The average width of the leave of Fruited Pumpkin in all the six treatments showed that sample A $(4.9 \mathrm{~cm}-11.0 \mathrm{~cm})$ treatment had the highest average leave width after 30 days of measurement followed by Sample C $(4.8 \mathrm{~cm}-10.7 \mathrm{~cm})$ treatment, N.P.K $(4.5 \mathrm{~cm}$ $10.3 \mathrm{~cm})$ sample and sample B $(4.6 \mathrm{~cm}-10.2 \mathrm{~cm})$ treatment while sample D $(4.6 \mathrm{~cm}-9.9 \mathrm{~cm})$ treatment and control $(4.1 \mathrm{~cm}-9.1 \mathrm{~cm})$ sample had the lowest average leave width respectively.

\section{Comparison of average height of spinach stem}

The average height of the stem showed that sample C $(16.8 \mathrm{~cm}$ $-77.3 \mathrm{~cm})$ treatment had the highest average stem height after 30 days of measurement, followed by samples B $(15.4 \mathrm{~cm}-76.4 \mathrm{~cm})$ treatment, N.P.K $(15.5 \mathrm{~cm}-71.3 \mathrm{~cm})$ fertilizer treatment and sample D $(14.4 \mathrm{~cm}-65.6 \mathrm{~cm})$ treatment while control $(14.3 \mathrm{~cm}-58.6 \mathrm{~cm})$ sample and sample A $(5.4 \mathrm{~cm}-52.7 \mathrm{~cm})$ treatment had the lowest stem height respectively. 


\begin{tabular}{|c|c|c|c|c|c|c|c|}
\hline Date & $\begin{array}{c}\text { Time } \\
\text { 9.00am }\end{array}$ & $\begin{array}{c}\text { Verm Sample } \\
\text { A (cm) }\end{array}$ & $\begin{array}{c}\text { Verm Sample } \\
\text { B (cm) }\end{array}$ & $\begin{array}{c}\text { Verm Sample } \\
\text { C (cm) }\end{array}$ & $\begin{array}{c}\text { Verm sample } \\
\text { D (cm) }\end{array}$ & $\begin{array}{c}\text { N.P.K 15:15:20 } \\
(\mathrm{cm})\end{array}$ & $\begin{array}{c}\text { Control } \\
\text { (cm) }\end{array}$ \\
\hline 2 & & 72.7 & 82.5 & 84.2 & 89.0 & 70.7 & 70.0 \\
\hline 4 & & 86.5 & 90.9 & 110.9 & 110.2 & 83.0 & 82.1 \\
\hline 5 & & 97.2 & 118.0 & 120.2 & 123.8 & 90.4 & 88.2 \\
\hline 6 & & 102.1 & 121.3 & 129.4 & 133.9 & 93.4 & 92.5 \\
\hline 8 & & 118.6 & 139.5 & 153.9 & 152.5 & 110.0 & 108.0 \\
\hline 9 & & 124.6 & 147.5 & 159.1 & 160.1 & 122.0 & 118.5 \\
\hline 10 & & 139.2 & 155.8 & 173.3 & 168.8 & 132.8 & 128.7 \\
\hline 11 & & 147.8 & 163.7 & 180.6 & 176.4 & 146.2 & 136.8 \\
\hline 12 & & 159.5 & 173.4 & 184.5 & 182.0 & 156.3 & 142.8 \\
\hline 13 & & 170.9 & 180.5 & 190.8 & 189.5 & 170.0 & 156.3 \\
\hline 17 & & 220.4 & 203.7 & 219.2 & 232.0 & 192.8 & 187.6 \\
\hline 18 & & 232.5 & 211.0 & 231.2 & 240.6 & 199.6 & 190.1 \\
\hline 19 & & 241.2 & 219.0 & 242.7 & 247.4 & 209.1 & 198.0 \\
\hline 20 & & 255.0 & 224.0 & 253.7 & 251.8 & 214.3 & 204.5 \\
\hline 21 & & 265.3 & 230.4 & 266.1 & 258.5 & 220.4 & 210.1 \\
\hline 22 & & 279.5 & 237.5 & 278.2 & 269.2 & 227.2 & 217.8 \\
\hline 23 & & 288.5 & 246.0 & 286.8 & 278.9 & 234.8 & 221.8 \\
\hline 24 & & 298.1 & 264.9 & 313.8 & 281.7 & 254.6 & 235.8 \\
\hline 25 & & 313.0 & 281.3 & 325.0 & 289.0 & 273.6 & 251.7 \\
\hline 26 & & 322.3 & 290.2 & 334.4 & 296.4 & 280.6 & 259.2 \\
\hline 27 & & 332.4 & 310.0 & 334.4 & 301.7 & 287.1 & 266.1 \\
\hline
\end{tabular}

Table 5: Average length of stem cord of Fruited Pumpkin as measured with meter tape and meter rule for a period of 30 days.

\begin{tabular}{|c|c|c|c|c|c|c|c|}
\hline Date & $\begin{array}{c}\text { Time } \\
\text { 9.00am }\end{array}$ & $\begin{array}{c}\text { Verm Sample } \\
\text { A(cm) }\end{array}$ & $\begin{array}{c}\text { Verm sample } \\
\text { B (cm) }\end{array}$ & $\begin{array}{l}\text { Verm Sample } \\
\text { C (cm) }\end{array}$ & $\begin{array}{c}\text { Verm sample } \\
\text { D (cm) }\end{array}$ & $\begin{array}{c}\text { N.P.K 15:15:20 } \\
\text { (cm) }\end{array}$ & $\begin{array}{c}\text { Control } \\
\text { (cm) }\end{array}$ \\
\hline $1 / 12 / 2017$ & & 12.2 & 10.2 & 10.4 & 10.0 & 10.1 & 9.1 \\
\hline 2 & & 12.6 & 10.7 & 10.9 & 10.3 & 10.4 & 9.3 \\
\hline 3 & & 12.9 & 11.1 & 11.3 & 10.6 & 10.7 & 9.6 \\
\hline 4 & & 13.3 & 11.5 & 11.7 & 10.9 & 11.0 & 9.9 \\
\hline 5 & & 13.6 & 11.8 & 11.9 & 11.2 & 11.4 & 10.3 \\
\hline 6 & & 13.9 & 12.2 & 12.3 & 11.5 & 11.8 & 10.7 \\
\hline 7 & & 14.2 & 12.6 & 12.6 & 11.8 & 12.3 & 11.1 \\
\hline 8 & & 14.8 & 13.0 & 12.9 & 12.0 & 12.7 & 11.5 \\
\hline 9 & & 15.2 & 13.3 & 13.5 & 12.6 & 12.9 & 11.8 \\
\hline 10 & & 15.5 & 13.7 & 13.8 & 12.8 & 13.6 & 12.2 \\
\hline 11 & & 15.9 & 14.0 & 14.3 & 13.3 & 14.1 & 13.0 \\
\hline 12 & & 16.1 & 14.5 & 14.8 & 13.5 & 14.6 & 13.5 \\
\hline 13 & & 16.4 & 14.7 & 15.4 & 13.8 & 15.2 & 14.1 \\
\hline 14 & & 16.8 & 15.2 & 16.0 & 14.2 & 15.9 & 14.4 \\
\hline 15 & & 17.3 & 15.6 & 16.6 & 14.7 & 16.3 & 14.8 \\
\hline 16 & & 17.5 & 15.9 & 17.1 & 14.9 & 16.8 & 15.3 \\
\hline 17 & & 17.8 & 16.3 & 17.6 & 15.3 & 17.2 & 15.9 \\
\hline 18 & & 18.0 & 16.5 & 17.9 & 15.9 & 17.7 & 16.4 \\
\hline 19 & & 18.3 & 16.9 & 18.4 & 16.4 & 18.1 & 16.9 \\
\hline 20 & & 18.5 & 17.3 & 18.9 & 16.9 & 18.4 & 16.4 \\
\hline 21 & & 18.9 & 17.6 & 19.3 & 17.0 & 18.6 & 17.0 \\
\hline 22 & & 19.1 & 17.8 & 19.5 & 17.4 & 18.8 & 17.3 \\
\hline 23 & & 19.4 & 18.1 & 19.9 & 17.6 & 19.0 & 17.5 \\
\hline 24 & & 19.7 & 18.4 & 20.1 & 17.9 & 19.2 & 17.7 \\
\hline 25 & & 20.0 & 18.7 & 20.3 & 18.0 & 19.4 & 17.8 \\
\hline 26 & & 20.2 & 18.9 & 20.6 & 18.2 & 19.6 & 18.0 \\
\hline 27 & & 20.5 & 19.3 & 20.9 & 18.4 & 19.7 & 18.2 \\
\hline 28 & & 21.7 & 19.5 & 21.2 & 18.5 & 19.9 & 18.3 \\
\hline 29 & & 22.2 & 19.9 & 21.5 & 18.7 & 20.3 & 18.4 \\
\hline 30 & & 22.5 & 20.0 & 22.0 & 18.8 & 20.6 & 18.5 \\
\hline
\end{tabular}

Table 6: Average length Fruited Pumpkin leaf as measured with meter tape and meter rule for a period of 30 days. 
Utilization of Organic Wastes in the Production of Biofertilizer (by Vermicompost using Eisenia fetida Earthworm) with Analysis of their Micro and Macro Mineral Nutrient and their Effects on Growth Rate of Fruited Pumpkin (Telfairia occidentalis) and Spinach (Spinacia oleracea)

117

\begin{tabular}{|c|c|c|c|c|c|c|c|}
\hline Date & $\begin{array}{c}\text { Time } \\
\text { 9.00am }\end{array}$ & $\begin{array}{c}\text { Verm Sample } \\
\text { a (cm) }\end{array}$ & $\begin{array}{l}\text { Verm sample } \\
\text { B (cm) }\end{array}$ & $\begin{array}{l}\text { Verm Sample } \\
\text { C (cm) }\end{array}$ & $\begin{array}{c}\text { Verm sample } \\
D(\mathrm{~cm})\end{array}$ & $\begin{array}{c}\text { N.p.k 15:15:20 } \\
(\mathrm{cm})\end{array}$ & $\begin{array}{l}\text { Control } \\
\text { (cm) }\end{array}$ \\
\hline $1 / 12 / 2017$ & & 4.9 & 4.6 & 4.8 & 4.6 & 4.5 & 4.1 \\
\hline 2 & & 5.1 & 4.8 & 5.0 & 4.8 & 4.7 & 4.3 \\
\hline 3 & & 5.3 & 4.9 & 5.2 & 4.9 & 4.8 & 4.5 \\
\hline 4 & & 5.6 & 5.1 & 5.4 & 5.1 & 4.9 & 4.7 \\
\hline 5 & & 5.8 & 5.2 & 5.6 & 5.3 & 5.1 & 4.9 \\
\hline 6 & & 5.9 & 5.3 & 5.7 & 5.4 & 5.3 & 5.1 \\
\hline 7 & & 6.1 & 5.5 & 5.9 & 5.6 & 5.5 & 5.2 \\
\hline 8 & & 6.3 & 5.7 & 6.1 & 6.0 & 5.7 & 5.4 \\
\hline 9 & & 6.6 & 5.9 & 6.3 & 6.1 & 5.9 & 5.5 \\
\hline 10 & & 6.8 & 6.0 & 6.4 & 6.3 & 6.0 & 5.7 \\
\hline 11 & & 7.0 & 6.2 & 6.6 & 6.4 & 6.3 & 5.8 \\
\hline 12 & & 7.1 & 6.4 & 6.8 & 6.6 & 6.5 & 5.9 \\
\hline 13 & & 7.3 & 6.7 & 7.0 & 6.7 & 6.8 & 6.1 \\
\hline 14 & & 7.4 & 6.9 & 7.2 & 6.9 & 7.0 & 6.3 \\
\hline 15 & & 7.6 & 7.1 & 7.3 & 7.1 & 7.1 & 6.5 \\
\hline 16 & & 7.9 & 7.2 & 7.5 & 7.2 & 7.2 & 6.6 \\
\hline 17 & & 8.2 & 7.4 & 7.7 & 7.3 & 7.4 & 6.8 \\
\hline 18 & & 8.4 & 7.5 & 7.8 & 7.5 & 7.6 & 7.0 \\
\hline 19 & & 8.7 & 7.7 & 7.9 & 7.7 & 7.8 & 7.2 \\
\hline 20 & & 8.9 & 7.9 & 8.2 & 7.9 & 8.1 & 7.3 \\
\hline 21 & & 9.0 & 8.0 & 8.4 & 8.0 & 8.2 & 7.4 \\
\hline 22 & & 9.1 & 8.2 & 8.6 & 8.2 & 8.4 & 7.5 \\
\hline 23 & & 9.3 & 8.4 & 8.9 & 8.3 & 8.6 & 7.7 \\
\hline 24 & & 9.5 & 8.7 & 9.1 & 8.5 & 9.0 & 8.0 \\
\hline 25 & & 10.0 & 9.2 & 9.5 & 8.8 & 9.3 & 8.3 \\
\hline 26 & & 10.2 & 9.3 & 9.7 & 9.0 & 9.4 & 8.5 \\
\hline 27 & & 10.4 & 9.4 & 9.9 & 9.2 & 9.5 & 8.7 \\
\hline 28 & & 10.7 & 9.7 & 10.2 & 9.4 & 9.8 & 8.8 \\
\hline 29 & & 10.9 & 9.9 & 10.4 & 9.7 & 10.0 & 8.9 \\
\hline 30 & & 11.0 & 10.2 & 10.7 & 9.9 & 10.3 & 9.1 \\
\hline
\end{tabular}

Table 7: Average width of Fruited Pumpkin leaf as measured with meter tape and meter rule for a period of 30 days.

\begin{tabular}{|c|c|c|c|c|c|c|c|}
\hline Date & $\begin{array}{l}\text { Time } \\
\text { 9.00am }\end{array}$ & $\begin{array}{l}\text { Verm Sample } \\
\text { a (cm) }\end{array}$ & $\begin{array}{c}\text { Verm sample } \\
\text { B (cm) }\end{array}$ & $\begin{array}{l}\text { Verm Sample } \\
\text { C (cm) }\end{array}$ & $\begin{array}{c}\text { Verm sample } \\
\text { D (cm) }\end{array}$ & $\begin{array}{c}\text { N.P.K 15:15:20 } \\
\text { (cm) }\end{array}$ & $\begin{array}{c}\text { Control } \\
\text { (cm) }\end{array}$ \\
\hline $1 / 12 / 2017$ & & 5.4 & 15.4 & 16.8 & 14.4 & 15.5 & 14.3 \\
\hline 2 & & 6.1 & 16.2 & 18.6 & 14.8 & 16.4 & 14.8 \\
\hline 3 & & 7.9 & 17.9 & 19.7 & 15.9 & 18.0 & 15.8 \\
\hline 4 & & 8.8 & 18.3 & 21.3 & 18.5 & 19.1 & 17.1 \\
\hline 5 & & 9.5 & 20.1 & 23.4 & 19.5 & 21.4 & 17.8 \\
\hline 6 & & 11.2 & 22.7 & 25.2 & 21.3 & 23.5 & 18.7 \\
\hline 7 & & 12.8 & 25.6 & 27.6 & 23.6 & 25.1 & 21.5 \\
\hline 8 & & 14.5 & 27.5 & 28.6 & 25.8 & 27.0 & 22.5 \\
\hline 9 & & 14.9 & 29.7 & 30.1 & 27.4 & 29.3 & 24.1 \\
\hline 10 & & 16.1 & 31.8 & 32.5 & 29.0 & 31.3 & 27.8 \\
\hline 11 & & 18.5 & 34.1 & 34.7 & 30.8 & 33.9 & 29.7 \\
\hline 12 & & 21.1 & 36.3 & 36.3 & 32.6 & 35.2 & 32.1 \\
\hline 13 & & 22.0 & 40.0 & 40.3 & 34.8 & 39.6 & 34.0 \\
\hline 14 & & 23.7 & 42.6 & 42.4 & 36.1 & 40.8 & 35.3 \\
\hline 15 & & 25.4 & 44.3 & 44.1 & 38.6 & 42.5 & 36.0 \\
\hline 16 & & 27.0 & 46.7 & 46.7 & 40.2 & 43.7 & 37.2 \\
\hline 17 & & 28.7 & 48.0 & 48.5 & 42.7 & 45.1 & 38.1 \\
\hline 18 & & 29.0 & 50.1 & 50.7 & 43.6 & 46.4 & 39.7 \\
\hline 19 & & 30.1 & 52.2 & 51.8 & 45.2 & 48.1 & 41.0 \\
\hline 20 & & 32.6 & 53.9 & 53.7 & 47.4 & 50.5 & 41.7 \\
\hline 21 & & 35.2 & 55.1 & 55.7 & 49.8 & 53.2 & 43.0 \\
\hline 22 & & 37.5 & 57.2 & 58.7 & 51.2 & 54.4 & 43.8 \\
\hline 23 & & 39.3 & 59.8 & 60.5 & 52.8 & 55.9 & 44.2 \\
\hline 24 & & 41.5 & 62.6 & 62.4 & 53.1 & 56.2 & 48.9 \\
\hline 25 & & 43.7 & 65.1 & 63.7 & 54.3 & 61.3 & 50.3 \\
\hline 26 & & 45.4 & 67.6 & 65.7 & 56.8 & 63.5 & 53.1 \\
\hline 27 & & 47.5 & 68.9 & 69.6 & 58.5 & 64.2 & 54.8 \\
\hline 28 & & 49.1 & 71.1 & 73.5 & 60.7 & 65.3 & 55.2 \\
\hline 29 & & 51.8 & 74.8 & 75.7 & 63.0 & 68.6 & 57.1 \\
\hline 30 & & 52.7 & 76.4 & 77.3 & 65.6 & 71.3 & 58.6 \\
\hline
\end{tabular}

Table 8: Average height of Spinach stem as measured with meter tape and meter rule for a period of 30 days.

Citation: Obianuju Ozioma Ezeorji., et al. "Utilization of Organic Wastes in the Production of Biofertilizer (by Vermicompost using Eisenia fetida Earthworm) with Analysis of their Micro and Macro Mineral Nutrient and their Effects on Growth Rate of Fruited Pumpkin (Telfairia occidentalis) and Spinach (Spinacia oleracea)". Acta Scientific Nutritional Health 4.2 (2020): 111-120. 
Utilization of Organic Wastes in the Production of Biofertilizer (by Vermicompost using Eisenia fetida Earthworm) with Analysis of their Micro and Macro Mineral Nutrient and their Effects on Growth Rate of Fruited Pumpkin (Telfairia occidentalis) and Spinach (Spinacia oleracea)

Comparison of average width of spinach leaf

The average width of Spinach leaf showed that sample C $(3.2 \mathrm{~cm}$ $-13.0 \mathrm{~cm}$ ) treatment had the highest average leaf width range after 30 days measurement, followed by sample B $(3.2 \mathrm{~cm}-12.9 \mathrm{~cm})$ treatment, sample A $(3.1 \mathrm{~cm}-12.8 \mathrm{~cm})$ treatment and N.P.K $(3.0 \mathrm{~cm}$ $-12.3 \mathrm{~cm})$ treatment while sample $D(2.8 \mathrm{~cm}-14.6 \mathrm{~cm})$ treatment and control $(6.0 \mathrm{~cm}-11.0 \mathrm{~cm})$ sample treatment had the lowest average leave width range respectively.

\section{Comparison of Average length of Spinach leaf}

For the average length of the Spinach leaf, the above chart showed that sample C $(7.7 \mathrm{~cm}-19.4 \mathrm{~cm})$ treatment had the highest leave length range after 30 days followed by sample $B(7.8 \mathrm{~cm}$ - $18.5 \mathrm{~cm})$, sample A $(6.7 \mathrm{~cm} 17.8 \mathrm{~cm})$ treatment and N.P.K $(6.1 \mathrm{~cm}$ - $16.3 \mathrm{~cm})$ samples respectively while sample D $(6.0 \mathrm{~cm}-14.8 \mathrm{~cm})$ treatment and control $(2.6 \mathrm{~cm}-14.6 \mathrm{~cm})$ had the lowest leaf length range respectively.

In general, the four vermicompost samples affected the growth parameters considered in Fruited Pumpkin and Spinach respectively. Vermicompost fertilizer treatment samples had better performance compared to N.P.K and Control in most of the parameters measured. This may be from the nutrient balance in organic manure which affects plant growth and development compared with chemical fertilizer [27]. According to [33], the materials used in the formulation of the vermicompost especially livestock manure, improved soil physical properties which in turn cause more stimulation of elements and water absorption by plant roots. Research has shown that vermicompost affects the physical and hydraulic features of the soil structure, increase rate of water penetration in the soil and aeration. Furthermore, vermicompost fertilizer significantly affected the yield of mustard and common bean especially in the area of better crop growth and yield [2,27]. Balancing of nutrient such as nitrogen and micronutrients affects the structure of chlorophyll and protein synthesis that led to the development of vegetative growth and leaf area in plants. As expected control soil sample had the lowest performance in all the growth parameters considered except for spinach stem height. This may be from the absorption of nutrient by the root system of the spinach from the soil [28]. In some cases, N.P.K fertilizer treatment sample slightly out performed some of the vermicompost sample treatment; this may be from the quick digestion and release of nutrient by chemical fertilizer for plant absorption. Again, the high content of nitrogen in the N.P.K fertilizer might have affected the growth rate of both pumpkin and spinach planted with N.P.K fertilizer sample since nitrogen enhances growth and development rate of plants [29].

\begin{tabular}{|c|c|c|c|c|c|c|c|}
\hline Date & $\begin{array}{l}\text { Time } \\
\text { 9.00am }\end{array}$ & $\begin{array}{c}\text { Verm Sample } \\
\text { a (cm) }\end{array}$ & $\begin{array}{c}\text { Verm sample } \\
\text { B (cm) }\end{array}$ & $\begin{array}{l}\text { Verm Sample } \\
\text { C (cm) }\end{array}$ & $\begin{array}{c}\text { Verm sample } \\
\text { D (cm) }\end{array}$ & $\begin{array}{c}\text { N.P.K 15:15:20 } \\
\text { (cm) }\end{array}$ & $\begin{array}{c}\text { Control } \\
\text { (cm) }\end{array}$ \\
\hline $1 / 12 / 2017$ & & 3.1 & 3.2 & 3.2 & 2.8 & 3.0 & 2.6 \\
\hline 2 & & 3.5 & 3.4 & 3.4 & 3.1 & 3.2 & 2.8 \\
\hline 3 & & 3.7 & 3.7 & 3.7 & 3.3 & 3.5 & 3.0 \\
\hline 4 & & 3.9 & 4.0 & 3.9 & 3.7 & 3.8 & 3.4 \\
\hline 5 & & 4.2 & 4.4 & 4.2 & 4.0 & 4.2 & 3.6 \\
\hline 6 & & 4.8 & 4.9 & 4.9 & 4.3 & 4.8 & 4.1 \\
\hline 7 & & 5.1 & 5.7 & 5.5 & 4.7 & 5.3 & 4.5 \\
\hline 8 & & 6.2 & 6.5 & 6.5 & 5.1 & 6.1 & 5.1 \\
\hline 9 & & 6.5 & 6.9 & 6.9 & 6.0 & 6.4 & 6.0 \\
\hline 10 & & 6.8 & 7.2 & 7.3 & 6.4 & 6.8 & 6.4 \\
\hline 11 & & 7.2 & 7.5 & 7.5 & 6.9 & 7.1 & 6.9 \\
\hline 12 & & 7.5 & 7.7 & 7.9 & 7.3 & 7.4 & 7.3 \\
\hline 13 & & 8.0 & 8.1 & 8.1 & 7.6 & 7.9 & 7.5 \\
\hline 14 & & 8.4 & 8.5 & 8.4 & 7.9 & 8.2 & 7.7 \\
\hline 15 & & 8.8 & 8.9 & 8.8 & 8.1 & 8.4 & 8.0 \\
\hline 16 & & 9.2 & 9.3 & 9.2 & 8.3 & 9.1 & 8.2 \\
\hline 17 & & 9.5 & 9.6 & 9.6 & 8.5 & 9.3 & 8.4 \\
\hline 18 & & 9.7 & 9.8 & 9.8 & 8.7 & 9.5 & 8.6 \\
\hline 19 & & 9.9 & 10.1 & 10.0 & 8.9 & 9.7 & 8.8 \\
\hline 20 & & 10.3 & 10.3 & 10.3 & 9.1 & 9.9 & 9.0 \\
\hline 21 & & 10.6 & 10.5 & 10.6 & 9.3 & 10.2 & 9.2 \\
\hline 22 & & 10.8 & 10.7 & 10.8 & 9.5 & 10.4 & 9.4 \\
\hline 23 & & 11.0 & 10.9 & 11.2 & 9.7 & 10.7 & 9.6 \\
\hline 24 & & 11.2 & 11.1 & 11.4 & 9.8 & 10.9 & 9.7 \\
\hline 25 & & 11.4 & 11.4 & 11.6 & 10.0 & 11.1 & 9.8 \\
\hline 26 & & 11.6 & 11.7 & 11.9 & 10.2 & 11.3 & 10.1 \\
\hline 27 & & 11.9 & 11.9 & 12.2 & 10.4 & 11.6 & 10.3 \\
\hline 28 & & 12.2 & 12.2 & 12.6 & 10.6 & 11.8 & 10.5 \\
\hline 29 & & 12.6 & 12.6 & 12.8 & 10.8 & 12.1 & 10.6 \\
\hline 30 & & 12.8 & 12.9 & 13.0 & 11.0 & 12.3 & 10.9 \\
\hline
\end{tabular}

Table 9: Average width of Spinach leaf as measured with meter tape and meter rule for a period of 30 days. 
Utilization of Organic Wastes in the Production of Biofertilizer (by Vermicompost using Eisenia fetida Earthworm) with Analysis of their Micro and Macro Mineral Nutrient and their Effects on Growth Rate of Fruited Pumpkin (Telfairia occidentalis) and Spinach (Spinacia oleracea)

\begin{tabular}{|c|c|c|c|c|c|c|c|}
\hline Date & Time 9.00am & $\begin{array}{l}\text { Verm Sample } \\
\text { a (cm) }\end{array}$ & $\begin{array}{c}\text { Verm sample } \\
\text { B (cm) }\end{array}$ & $\begin{array}{l}\text { Verm Sample } \\
\text { C (cm) }\end{array}$ & $\begin{array}{c}\text { Verm sample } \\
\text { D (cm) }\end{array}$ & $\begin{array}{l}\text { N.P.K 15:15:2 } \\
\text { (cm) }\end{array}$ & $\begin{array}{c}\text { Control } \\
\text { (cm) }\end{array}$ \\
\hline $1 / 12 / 2017$ & & 6.7 & 7.8 & 7.7 & 6.0 & 6.1 & 5.6 \\
\hline 2 & & 7.3 & 7.9 & 7.9 & 6.4 & 6.5 & 6.1 \\
\hline 3 & & 7.6 & 8.5 & 8.2 & 6.9 & 7.3 & 7.2 \\
\hline 4 & & 7.9 & 8.8 & 8.6 & 7.2 & 7.5 & 7.4 \\
\hline 5 & & 8.0 & 9.0 & 9.2 & 7.6 & 7.8 & 7.6 \\
\hline 6 & & 8.3 & 9.3 & 9.6 & 7.9 & 8.2 & 7.9 \\
\hline 7 & & 8.6 & 9.5 & 9.9 & 8.2 & 8.4 & 8.1 \\
\hline 8 & & 8.9 & 9.8 & 10.3 & 8.4 & 8.6 & 8.3 \\
\hline 9 & & 9.2 & 10.0 & 10.8 & 8.7 & 8.9 & 8.5 \\
\hline 10 & & 9.4 & 10.3 & 11.3 & 8.9 & 9.2 & 8.9 \\
\hline 11 & & 9.9 & 10.3 & 11.7 & 9.2 & 9.6 & 9.2 \\
\hline 12 & & 10.3 & 11.4 & 11.9 & 9.6 & 10.0 & 9.5 \\
\hline 13 & & 11.6 & 11.7 & 12.4 & 9.9 & 10.3 & 9.8 \\
\hline 14 & & 11.9 & 11.9 & 12.8 & 10.1 & 10.6 & 10.0 \\
\hline 15 & & 12.4 & 12.2 & 13.1 & 10.3 & 11.0 & 10.3 \\
\hline 16 & & 12.8 & 12.7 & 13.5 & 10.7 & 11.4 & 10.5 \\
\hline 17 & & 13.1 & 13.2 & 13.9 & 10.9 & 11.8 & 10.8 \\
\hline 18 & & 13.5 & 13.5 & 14.3 & 11.2 & 12.2 & 11.0 \\
\hline 19 & & 13.7 & 13.9 & 14.9 & 11.5 & 12.4 & 11.3 \\
\hline 20 & & 13.9 & 14.4 & 15.4 & 11.8 & 12.9 & 11.7 \\
\hline 21 & & 14.7 & 14.8 & 15.8 & 12.0 & 13.2 & 11.9 \\
\hline 22 & & 15.2 & 15.3 & 16.3 & 12.3 & 13.8 & 12.1 \\
\hline 23 & & 15.4 & 15.8 & 16.5 & 12.6 & 14.2 & 12.4 \\
\hline 24 & & 15.7 & 16.0 & 16.7 & 12.7 & 14.5 & 12.6 \\
\hline 25 & & 16.1 & 16.2 & 16.9 & 12.9 & 14.7 & 12.8 \\
\hline 26 & & 16.5 & 16.7 & 17.3 & 13.7 & 15.0 & 13.0 \\
\hline 27 & & 16.9 & 17.1 & 17.9 & 13.7 & 15.6 & 13.4 \\
\hline 28 & & 17.2 & 17.6 & 18.4 & 14.0 & 15.9 & 13.8 \\
\hline 29 & & 17.7 & 18.1 & 18.8 & 14.4 & 16.0 & 14.0 \\
\hline 30 & & 17.8 & 18.5 & 19.4 & 14.8 & 16.3 & 14.6 \\
\hline
\end{tabular}

Table 10: Average length of Spinach leaf as measured with meter rule and meter tape for a period of 30 days.

\section{Conclusion}

Based on the research findings, the four vermicompost fertilizer samples outperformed the normal N.P.K 15:15:20 chemical fertilizer sample in terms of all the micro and macro mineral nutrients considered, it also affected the growth of Fruited Pumpkin and Spinach in some of the growth parameters considered compared to chemical fertilizer. It can be concluded that vermicompost can be used instead of chemical fertilizer in the cultivation of fruit and vegetables since they are more environmental friendly, cheap, with no adverse effect on human, plant and aquatic health.

\section{Authors Contribution}

This is our Original collaborative work. Author OOE designed the study, conducted literature searches, managed analysis of the study and wrote the manuscript. Author AJC coordinated the entire study read and supervised the analyses and approved the final manuscript for publication. Author $\mathrm{CCO}$ assisted in writing the manuscript, discussion and literature search.

\section{Conflict of Interest}

The authors declare that they have no conflict interests.

\section{Bibliography}

1. Mittal R and Mittal CG. "Impact of Population explosion on environment". We School "Knowledge Builder" The National Journal 1.1 (2013): 1-5.
2. Mondal T., et al. "Chemical Fertilizer in Conjunction with Biofertilizer and Vermicompost induced Changes in Morphophysiological and bio-chemical traits of mustard crop". Journal of the Saudi Society of Agricultural Science (2015).

3. Chandini., et al. "The Impart of Chemical Fertilizers on our Environment and Ecosystem". Research Gate Publication 5 (2019): 69-85.

4. Sabiiti EN. "Utilising Agricultural Waste to enhance Food Security and Conserve the Environment". African Journal of Food, Agriculture, Nutrition and Development 11.6 (2011): 1-9.

5. Sneha S., et al. "Biofertilizere for Crop Production and Soil Fertility". Academic Journal of Agricultural Resource 6.8 (2018): 299-306.

6. Saeed KS., et al. "Effect of bio-fertilizer and Chemical fertilizer on growth and yield in Cucumber (Cucumis sativas L.) in green House condition". American-Eurasian Journal of Agric and Environmental Science 15.3 (2015): 353-358.

7. Fernia A and Hasanpour K. "Comparison between effect of Chemical and Biochemical fertilizers on yield and yield component in wheat (Triticum aestivum L.)". Indian Journal of Natural Science 5.30 (2015): 7792-7800.

8. Bhattacharjee R and Dey U. "Biofertilizer, a way towards organic agriculture: A review". African Journal of Microbiology Research 8.24 (2014): 2332-2342.

9. Devi J and Sumathy VJH. "Production of Biofertilizer from Agro-waste". International Journal of Engineering and Technique 4.1 (2018): 453-466. 
Utilization of Organic Wastes in the Production of Biofertilizer (by Vermicompost using Eisenia fetida Earthworm) with Analysis of their Micro and Macro Mineral Nutrient and their Effects on Growth Rate of Fruited Pumpkin (Telfairia occidentalis) and Spinach (Spinacia oleracea)

10. Kumar R., et al. "Role of Biofertilizer in Agriculture". Popular Kheti. 5.4 (2017): 63-66.

11. Devi J and Prakash M. "Microbial Population dynamic during Vermicomposting of three Different Substrate amended with Cow dung". International Journal of Current Microbiology and Applied Sciences 4.2 (2015): 1086-1092.

12. Gajalashmi S and Abassi SA. "Earth worms and Vermicomposting". International Journal of Biotechnology 3 (2004): 486-494.

13. Ramnarain YI., et al. "Vermicomposting of different organic materials using the Epigeic earth worm Eisenia foetida". International Journal of Recycling of Organic Waste in Agriculture 8 (2019): 23-36.

14. Getachew Z., et al. "Vermicompost Potential of Common Earthworms (Eurilus eugeniae) and Red Wiggler (Eisenia fetida) Worm on the Decomposition of various organic Waste". International Journal of Plant and Soil Science 24.3 (2018): 1-13.

15. Islam AM., et al. "Effect of Organic and Inorganic fertilizers on soil properties and the growth, yield and quality of Tomato in Mymensigh, Bangladesh". Agriculture 7.18 (2017): 1-7.

16. Akenga P., et al. "Determination of Selected Micro and Macronutrients in Sugarcane growing Soil at Kakamega North District, Kenya". IORS Journal of Applied Chemistry 7.7 (2014): 34-41.

17. Ju I., et al. "A review: Biofertilizer - A key Player in Enhancing Soil Fertility and Crop Productivity". Journal of Microbiology Biotechnology Report 2.1 (2018): 22-28.

18. Devi V and Sumathy VJH. "Production of Fertilizer from fruit wastes". European Journal of Pharmaceutical and Medical Research 4.9 (2017): 436-443.

19. Achikanu CE., et al. "Determination of the Vitamin and Mineral Composition of common Leafy Vegetables in South Eastern Nigeria". International Journal of Current Microbiology and Applied Science 4.11 (2013): 347-353.

20. Hinkelmann $\mathrm{K}$ and Kempthrone 0. "Design and Analysis of Experiment, Volume 1: Introduction to Experimental design" Wiley (2003).

21. Jardao CP., et al. "Heavy metal availability in soil amended with Composed Urban Solid wastes". Journal of Environmental Monitoring 112 (2006): 309-326.

22. Millaleo R., et al. "Manganese as Essential and Toxic Element for Plants: Transport, Accumulation and Resistance Mechanism". Journal of Soil Science and Plant Nutrition 10.4 (2010): 470-481.

23. Senbayram M., et al. "Role of Magnesium and fertilizer in Agriculture; Plant soil Continum". Crop and Pasture Science 66 (2015): 1219-1229.
24. Porkodi P and Amruththa M. "Comparative Studies on the Nutrient Levels of Vermicompost by Eisenia fetida and Eudrilus eugeniae and their Effects on Vigna radiate". IOSR Journal of Environmental Science, Toxicology and Food Technology 8.12 (2014): 78-82.

25. Prajapati K and Modi HA. "The Important of Potassuim in Plant Growth- A review". Indian Journal of Plant Science 1.02-03 (2012): 177-186.

26. Surtha S. "Nutrient Changes and Bio-dynamics of Epigeic Earthworth Perionyx excavatuus during recycling of some agricultural waste". Bioresources Technology 98 (2007): 16081614.

27. Sadeghipour 0. "Comparison the Effects of Vermicompost and Chemical Fertilizers on Growth and Yield of Common Bean (Phaseolus Vulgaris)". International Conference on Advances in Engineering Science: ICAES (2017).

28. Fageria NK and Moreira A. "The Role of Mineral Nutrition on Root Growth of Crop Plants". Advances in Agronomy 110 (2011): 251-331.

29. Chidambaram ALA., et al. "Effect of Vermicompost on the growth and Nutrient Status in Groundnut (Arachis hypogaea. L)". Asian Journal of Plant Science and Research 3.2 (2013): 1522.

30. Chinweuba AJ., et al. "Comparative Analysis of Macro and Micro nutrient of Bio waste, compost and Vermicompost (Using indigenous Lumbricus terrestis) solanum melongena (fruit) waste". Journal of Science and Engineering Research. 4.3(2017): 102-104.

31. Nandhini, E and Sumathi S. "Conversion of Solid Waste into Bio fertilizer by Vermicompost Method". International Journal of Pharma Science and Research 8.3(2017) : 24-32.

32. Daman R., et al. "Determination of Micronutrients in Vermicompost Prepared with Waste Rose Flower ( Rosa berberia) Collected from Religious Place of Patna". Research Journal of Chemical and Environmental Science. 4.5(2016): 3743.

33. Pirzard A., et al. "Effect of bio fertilizers on the yield and yields components of Cucurbita pepo L.". Bio Technology An Indian Journal 7.6(2013): 207214.

\section{Assets from publication with us}

- Prompt Acknowledgement after receiving the article

- Thorough Double blinded peer review

- Rapid Publication

- Issue of Publication Certificate

- High visibility of your Published work

Website: https://www.actascientific.com/

Submit Article: https://www.actascientific.com/submission.php Email us: editor@actascientific.com Contact us: +919182824667

Citation: Obianuju Ozioma Ezeorji., et al. "Utilization of Organic Wastes in the Production of Biofertilizer (by Vermicompost using Eisenia fetida Earthworm) with Analysis of their Micro and Macro Mineral Nutrient and their Effects on Growth Rate of Fruited Pumpkin (Telfairia occidentalis) and Spinach (Spinacia oleracea)". Acta Scientific Nutritional Health 4.2 (2020): 111-120. 